\title{
PENGEMBANGAN DIRI GURU-GURU MATEMATIKA SE-KABUPATEN TTU MELALUI KEGIATAN BIMTEK PENULISAN PROPOSAL DAN ARTIKEL ILMIAH
}

\author{
${ }^{1)}$ Oktovianus Mamoh, ${ }^{2)}$ Hendrika Bete ${ }^{2}$ \\ Pos-El: oktomamoh01@ gmail.com ${ }^{1)}$ \\ Program Studi Pendidikan Matematika, Fakultas Ilmu Pendidikan, Universitas Timor, Indonesia ${ }^{1,2)}$
}

\begin{abstract}
Abstrak
Tujuan pengabdian ini agar dapat membantu guru-guru matematika se-kabupaten Timor Tengah Utara dalam mengembangkan diri melalui kegiatan Bimbingan Teknis (BIMTEK) Penulisan Proposal dan Artikel Ilmiah terutama Penelitian Tindakan Kelas (PTK). Sesuai tuntutan profesionalisme guru, maka PTK merupakan suatu kewajiban sehingga mutu pembelajaran pada kelas dan sekolah dapat terangkat serta masalah- masalah yang terdapat dalam pembelajaran dapat teratasi. Pengabdian ini dilaksanakan di SDN Sasi pada 14-16 Agustus 2018. Jumlah peserta yang hadir sebanyak 40 orang dengan pesertanya adalah guru - guru SD, guru-guru sekolah SMP bahkan ada guru TK. Kegiatan BIMTEK ini diawali dengan pemberian materi konsep umum PTK dan dilanjutkan dengan penulisan proposal PTK serta pendampingan penulisan proposal PTK. Kemudian dilanjutkan dengan teknik penulisan laporan PTK dan teknik penulisan artikel ilmiah. Pada sesi tanya jawab umpan balik, banyak peserta yang memberikan respon dan mengakui kesempatan kali ini banyak hal teknis penulisan ilmiah yang cukup mendalam dan tajam yang kami dapatkan dibandingkan dengan kegiatan-kegiatan terdahulu yang pernah kami ikuti. Kami berharap dan usahakan agar konsep rancangan penelitian yang telah dikonsepkan akan berlanjut hingga menjadi artikel ilmiah. Perwakilan Dinas Pendidikan, Pemuda dan Olahraga juga memberikan respon agar kegiatan yang dilakukan ini semoga dapat ditindaklajuti agar harapan untuk menghasilkan karya tulis ilmiah dapat tercapai.
\end{abstract}

Kata Kunci: Penelitian Tindakan Kelas, Guru Profesional, Artikel ilmiah

\section{Abstract}

The purpose of this service is to be able to help mathematics teachers in all districts of North Central Timor in developing themselves through the Technical Guidance (BIMTEK) Writing Proposals and Scientific Articles, especially Classroom Action Research (CAR). In accordance with the demands of teacher professionalism, CAR is an obligation so that the quality of learning in class and school can be raised and the problems contained in learning can be overcome. This dedication was held at SDN Sasi on August 14-16, 2018. The number of participants who attended was 40 people with the participants being elementary school teachers, junior high school teachers and even having kindergarten teachers. The BIMTEK activities began with the presentation of the general concept of CAR and continued with the writing of the CAR proposal and the assistance of the CAR proposal writing. Then proceed with the PTK report writing technique and scientific article writing techniques. In the question and answer feedback session, many participants responded and acknowledged the opportunity this time there were many technical matters of scientific writing that were quite deep and sharp that we got compared to previous activities that we had participated in. We hope and try so that the concept of research design that has been conceptualized will continue to become a scientific article. Representatives of the Department of Education, Youth and Sports also responded that the activities carried out hopefully could be followed up so that the hope to produce scientific papers could be achieved.

Keywords: Classroom action research, Professional Teachers, Scientific Articles PENDAHULUAN 
Guru memiliki peran yang sangat penting dalam proses pendidikan menuju masyarakat modern. Oleh karena itu, guru merupakan salah satu kunci dalam mempersiapkan generasi masa depan dalam menghadapi tantangan zaman yang semakin meningkat. Fungsi guru tidak hanya sekedar mengajar dan mendidik siswa menjadi cerdas, tetapi juga menghantar siswa untuk dapat mentransferkan ilmu dan nilai - nilai akademisnya pada masyarakat.

Selain profesi guru sebagai tenaga pengajar dan pendidik, guru juga dituntut untuk dapat menulis dan meneliti kenyataan - kenyataan yang terjadi dalam proses pembelajaran dengan membuat karya ilmiah. Dwiloka (2005: 2) menyatakan bahwa karya ilmiah adalah hasil pemikiran ilmiah seorang ilmuan yang ingin mengembangkan ilmu pengetahuan, teknologi, dan seni melalui kepustakaan, observasi, penelitian dan pengetahuan yang lain. Peningkatkan mutu pembelajaran guru juga dituntut untuk melakukan penelitian tindakan kelas. Suwandi (2007: 13) yang mengatakan bahwa PTK bertujuan untuk meningkatkan kinerja guru dan hasil belajar siswa, bukan saja mengungkapkan penyebab berbagai permasalahan yang dihadapi dalam proses pembelajaran.

Pengabdian masyarakat selama tiga tahun terakhir tentang pelatihan penulisan proposal PTK merasa tertarik untuk melakukan pengabdian dosen terhadap guru - guru matematika se- kabupaten Timor Tengah Utara. Selain itu penulis juga merasa penting karena tuntutan profesional guru bukan hanya pandai mengajar tetapi juga mampu membuat tulisan / karya tulis terutama golongan IV harus mempublikasikan tulisan pada artikel ilmiah.

Berdasarkan tuntutan profesional guru tersebut, maka guru mau tidak mau harus membuat karya ilmiah, membuat proposal penelitian tindakan kelas, membuat laporan hasil bahkan publikasi pada artikel ilmiah. Namun kenyataan, banyak guru tidak mampu menulis, tidak mampu membuat proposal PTK dan bahkan lebih dari itu tidak mampu membuat artikel ilmiah. Berdasarkan hasil wawancara penulis dengan guru- guru matematika mengatakan bahwa, sebagian guru - guru masih mengalami kesulitan dalam membuat karya ilmiah. Karena itu salah satu tujuan penulis adalah untuk meningkatkan mutu guru matematika dalam membuat proposal PTK dan artikel ilmiah.

Penelitian Tindakan Kelas (Class Room Action Research) berarti penelitian yang dilakukan dengan tindakan pada sebuah kelas untuk mengetahui akibat tindakan yang diterapkan pada suatu subyek penelitian di kelas tersebut (Siswono, 2010).

Secara luas, PTK diartikan sebagai penelitian yang berorientasi pada penerapan tindakan dengan tujuan peningkatan mutu atau pemecahan masalah pada sekelompok subyek yang diteliti dan mengamati tingkat keberhasilan atau akibat tindakannya, untuk kemudian diberikan tindakan lanjutan yang bersifat penyempurnaan tindakan atau penyesuaian dengan kondisi dan situasi sehingga diperoleh hasil yang lebih baik. Tindakan yang secara sengaja diberikan tersebut diberikan oleh guru atau berdasarkan arahan guru yang kemudian dilakukan oleh siswa. Disebut pekerjaan guru maka penelitian tindakan yang dilakukan disebut Penelitian Tindakan Kelas (Sudarsono, 2001). Selain defenisi di atas, Raka mendefinikan PTK sebagai kajian yang bersifat reflektif oleh pelaku tindakan untuk meningkatkan kemampuan rasional dari tindakan yang dilakukan, serta memperbaiki kondisi pembelajaran ( Mamoh, 2018).

Dengan demikian, PTK adalah suatu kegiatan penelitian dengan mencermati sebuah kegiatan belajar yang diberi tindakan, yang secara sengaja dimunculkan dalam sebuah kelas, yang bertujuan memecahkan masalah atau meningkatkan mutu pembelajaran di kelas 
tersebut. Kelas yang dimaksud adalah sekelompok siswa yang dalam waktu yang sama, menerima pelajaran yang sama dari guru yang sama juga (Arikunto, Suhardjono, Supardi 2008).

Tujuan PTK menurut beberapa ahli sebagai berikut:

a. PTK bertujuan untuk mengkaji situasi sosial dengan maksud untuk meningkatkan kualitas tindakan. Seluruh prosesnya, telaah, diagnosis perencanaan, pelaksanaan, pemantauan, dan pengaruh menciptakan hubungan yang diperlukan antara evauasi dan perkembangan professional. Pendapat yang mirip adalah Kemmis dan Mc Taggart, yang mengatakan bahwa PTK adalah suatu bentuk reflektif diri kolektif yang dilakukan oleh peserta pesertanya dalam situasi sosial untuk meningkatkan penalaran dan keadilan praktek terhadap situasi tempat dilakukan praktek tersebut.

b. PTK merupakan suatu pendekatan yang bertujuan untuk memperbaiki pendidikan melalui perubahan, dengan mendorong para guru untuk memikirkan praktek mengajarnya sendiri, agar kritis terhadap praktek tersebut dan agar mau mengubahnya.

c. Berdasarkan pendapat pendapat di atas jelas bahwa tujuan dilakukan PTK adalah dalam rangka guru bersedia untuk mengintrospeksi, bercermin, merefleksi atau mengevaluasi dirinya sendiri hingga kemampuannya sebagai seorang guru atau pengajar diharapkan cukup professional. Selanjutnya diharapkan dari peningkatan kemampuan diri tersebut dapat berpengaruh terhadap peningkatan kualitas anak didiknya baik dalam aspek penalaran, keterampilan, pengetahuan, hubungan sosial maupun aspek aspek lain yang bermanfaat bagi anak didik untuk menjadi dewasa.

d. Tujuan utama PTK adalah untuk mengubah perilaku pengajaran guru, perilaku peserta didik di kelas, peningkatan atau perbaikan praktek pembelajaran dan atau mengubah perangkat kerja melaksanakan pembelajaran kelas yang diajar oleh guru tersebut sehingga terjadi peningkatan layanan profesional guru dalam menangani proses pembelajaran. Jadi PTK dimaksudkan untuk mengembangkan keterampilan atau pendekatan baru pembelajaran dan untuk memecahkan masalah dengan penerapan langsung di ruang kelas.

e. Berdasarkan uraian di atas PTK merupakan penelitian yang dilakukan secara sistematis reflektif terhadap berbagai tindakan yang dilakukan oleh guru, mulai dari perencanaan sampai dengan penilaian terhadap tindakan nyata dalam proses pembelajaran di dalam kelas, yang bertujuan untuk memperbaiki kondisi pembelajaran yang dilakukan tersebut. Dengan demikian, tujuan dilaksanakannya PTK untuk meningkatkan kwalitas pendidikan dan atau pengajaran yang dilakukan oleh guru/pengajar/peneliti itu sendiri yang dampaknya diharapkan tidak ada lagi permasalahan yang mengganjal dalam proses pembelajaran di kelas.

PTK berfungsi sebagai alat untuk meningkatkan kwalitas pelaksanaan pembelajaran di kelas, antara lain:

a. Alat untuk mengatasi masalah masalah yang didiagnosis dalam situasi pembelajaran di kelas.

b. Alat pelatihan dalam jabatan, membekali guru dengan keterampilan dan metode baru dan mendorong timbulnya kesadaran diri, khususnya melalui pengajaran sejawat

c. Alat untuk memasukkan ke dalam sistem yang ada (secara alami) pendekatan tambahan atau inovasi. 
d. Alat untuk meningkatkan komunikasi yang biasanya buruk antara guru dan peneliti

e. Alat untuk menyediakan alternatif bagi pendekatan yang subjektif.

f. Alat untuk mengembangkan keterampilan guru yang bertolak dari kebutuhan untuk menanggulangi berbagai permasalahan pembelajaran aktual yang dihadapi di kelas.

Beberapa karakteristik PTK adalah sebagai berikut

(a). Didasarkan pada masalah keseharian yang dirasakan dalam melaksanakan pembelajaran yang selalu muncul, sekalipun siswa yang dihadapi berlainan.

(b). a Collaborative effort and or partisipative yang mengisyaratkan bahwa upaya perbaikan dilakukan bersama-sama peserta secara kolaboratif dan partisipatif.

(c). a reflective practice mode public, menghendaki keseluruhan proses implementasi tindakan dipantau dengan mempergunakan metode dan alat yang dapat dipertanggungjawabkan secara ilmiah.

Lebih jelas lagi karakteristik PTK dapat disebutkan :

(1) Situasional : artinya berkaitan langsung dengan permasalahan konkret yang dihadapi guru dan siswa di kelas.

(2) Kontekstual : Artinya upaya pemecahan yang berupa model dan prosedur tindakan tidak lepas dari konteksnya.

(3) Kolaboratif : adanya partisipasi antara guru-siswa dan orang yang terkait membantu proses pembelajaran. Kolaborasi didasarkan adanya tujuan yang sama.

(4) Self-reflective dan self-evaluatif pelaksana, pelaku tindakan, serta obyek yang dikenai tindakan melakukan refleksi dan evaluasi diri terhadap hasil atau kemajuan yang dicapai. Modifikasi perubahan yang dilakukan didasarkan pada hasil refleksi dan evaluasi yang mereka lakukan.

(5) Fleksibel dalam arti memberikan sedikit kelonggaran dalam pelaksanaan tanpa melanggar kaidah metodologi ilmiah. Misalnya tidak ada sampling, alat pengumpul data bersifat informal, sekalipun dimungkinkan dipakainya instrumen formal sebagaimana dalam penelitian eksperimental.

\section{Langkah-langkah pelaksanaan PTK}

a. Identifikasi dan Formulasi masalah

Formulasi masalah peneltian merupakan langkah awal yang menentukan keberhasilan langkah-langkah selanjutnya. Masalah dalam PTK mempunyai karakteristik spesifik bahwa peneliti tidak berada di luar apa yang diteliti tetapi berada di dalamnya, dimana guru terlibat langsung dalam pelaksanaan PTK. Oleh karena itu dengan memilih masalah yang tepat guru sebagai peneliti dapat melakukan perbaikan, peningkatan dan perubahan pembelajaran menjadi lebih baik.

Masalah yang layak diangkat sebagai masalah PTK yaitu :

1).Masalah menunjukkan adanya kesenjangan antara teori dan fakta empirik yang dirasakan pada saat PBM.

2).Adanya kemungkinan dicarikan alternatif solusinya melalui tindakan konkret yang dapat dilakukan guru dan siswa. 
3).Masalah tersebut memungkinkan dicari dan diidentifikasi faktor-faktor yang menimbulkannya.

b. Signifikansi Masalah PTK

Masalah yang dipilih untuk diangkat dalam PTK hendaknya mempunyai nilai yang bukan hanya sesaat dan memungkinkan diperoleh model tindakan efektif yang dapat dipakai guna memecahkan masalah yang mirip atau sejenis.

Pertanyaan yang dapat diajukan untuk mengkaji masalah misalnya sebagai berikut :

1). Apakah masalah teridentifikasi dan terformulasi secara jelas dan benar ?

2). Apakah ada masalah lain yang terkait dengan masalah yang akan diteliti ?, jika ya apakah telah terumuskan secara spesifik dan jelas ?

3). Apakah ada bukti empirik yang memperlihatkan nilai berharga untuk perbaikan praktek dan perbaikan pembelajaran ?.

c. Sumber masalah

Masalah PTK harus bersumber dari guru sendiri dan bukan berasal dari orang lain.

d. Formulasi Masalah

Hal-hal yang perlu diperhatikan dalam memformulasikan masalah :

1). Aspek substansi : perlu dilihat bobot kegunaan manfaat pemecahan masalah melalui tindakan.

2). Aspek Formulasi : masalah hendaknya dirumuskan dalam bentuk kalimat pertanyaan dan bukan merupakan pernyataan.

3). Aspek teknis : menyangkut kemampuan dan kelayakan peneliti untuk melakukan penelitian terhadap masalah yang dipilih.

e. Analisis Masalah merupakan kajian terhadap permasalahan dilihat dari segi kelayakannya, meliputi :

1). Konteks, situasi dimana masalah terjadi

2). Kondisi prasyarat terjadinya masalah

3). Keterlibatan komponen, aktor dalam terjadinya masalah

4). Kemungkinan adanya alternatif solusi yang dapat diajukan

5). Ketepatan waktu, lama waktu yang diperlukan untuk pemecahan masalah.

Analisis masalah ini digunakan untuk merancang rencana tindakan dan keterlibatan peran kolaborasi, waktu dalam siklus.

\section{METODE}

Metode yang digunakan dalam pelatihan ini adalah survey, observasi, ceramah dan latihan penulisan karya ilmiah. Jumlah peserta yang hadir pada kegiatan ini sebanyak 45 terdiri dari guru - guru matematika SD dan SMP yang ada di kota Kefamenanu dan luar kota kefamenanu.I

\section{HASIL DAN PEMBAHASAN}

Awal rancangan kegiatan ini adalah pelatihan penulisan proposal dan artikel ilmiah bagi guru-guru matematika se-Kabupaten TTU. Namun saat konsultasi dengan Dinas Pendidikan, maka nama kegiatan pelatihan diganti dengan nama bimbingan teknis (BIMTEK) karya tulis ilmiah pada guru-guru matematika se-kabupaten TTU. Hal ini dimaksudkan agar dapat disesuaikan dengan kebutuhan masyarakat. Peserta kegiatan ini juga tidak hanya terbatas pada guru-guru matematika. Namun, peserta datang dari berbagai sekolah dan latar belakang ilmu masing-masing yang berbeda-beda. Ada guru TK, ada guru 
SD dengan berbagai latar belakang keilmuan yang dimiliki, misalnya guru kelas dan guru matapelajaran, ada juga guru SMP dari berbagai profesi.

Kegiatan Bimbingan Teknik (BIMTEK) ini dilaksanakan pada tanggal $14-16$ Agustus 2018. Kegiatan BIMTEK ini dibuka dengan resmi oleh Kepala Dinas PPO yang diwakilkan oleh Bapak Matias Subani S. Pd., M. Pd, selaku Kepala bidang Tendik SD-SMP se-Kabupaten TTU. Kegiatan pengabdian selama tiga hari terlaksana dengan baik dan diikuti secara antusias oleh guru - guru.

1. Kegiatan Hari Pertama.

Pada hari pertama ini, materi yang diberikan adalah gambaran umum Penelitian tindakan kelas (PTK) yang dibawakan oleh ketua pengabdi, Oktovianus Mamoh, S.Pd., M.Pd. Sebelum memberikan materi, diawali dengan pertanyaan pemahaman para guru tentang PTK. Berikut, beberapa jawaban yang diberikan:

a. PTK terkait dengan belajar mengajar di dalam kelas, di dalamnya terdapat masalah dan tindakan.

b. Kondisi dan praktek-praktek

c. Suatu kegiatan yang dilaksanakan guru di dalam kelas. Guru mencermati dan mengamati sikap siswa di dalam kelas dan dalam mengajar guru menemukan, menjelaskan masalah di dalam kelas, sehingga harus dituangkan dalam karya tulis.

d. Penelitian tindakan kelas, karena ada masalah dikelas. Masalah itu bisa berasal dari guru, siswa dan juga fasilitas di dalam kelas. Sehingga perlu dicari solusi untuk masalah-masalah ini, sehingga dapat dituangkan dalam PTK.

Dari berbagai pandangan para peserta tentang PTK ini, pemateri melihat bahwa pemahaman mereka masih kurang. Karena itu pemateri melanjutkan dengan memberikan gambaran umum tentang PTK.

Saat diskusi, banyak pertanyaan yang diajukan oleh guru - guru yang berkaitan dengan PTK dan teknik penulisannya serta bagaimana menulis artikel juga untuk publikasi.

Diskusi penulis dengan para guru berjalan baik, sehingga guru - guru yang awalnya belum terlalu paham dengan penulisan karya ilmiah setelah mengikuti BIMTEK tersebut guru - guru semakin paham. Untuk sementara penulis dalam proses menyelesaikan proposal akhir pengabdian.

2. Kegiatan Hari Kedua

Materi hari kedua, tentsng teknik penulisan laporan PTK yang dibawakan oleh ketua peneliti. Pada saat ini diawali dengan pertanyaan umpan balik tentang PTK secara umum dan juga pengalaman para guru senior dalam melakukan laporan pembuatan PTK. Saat ditanya tentang sistematika yang mereka gunakan, mereka menjawab bahwa sistematika yang mereka gunakan hanya menggunakan contoh-contoh yang sudah ada. Mereka juga tidak mengerti apa-apa yang perlu ditulis. Salah satu hal yang mereka bingung adalah bagaimana bagaimana menentukan teori-teori yang ingin ditulis dilandasan teori. Semua permasalahan yang mereka alami, penulis menjelaskan dengan baik sampai mereka mengerti. Terutama sistematika penulisan, digambarkan semua termasuk isi dari setiap poin yang harus dikaji.

3. Kegiatan Hari Ketiga 
Pada hari ketiga, para pemateri memberikan gambaran tentang artikel ilmiah yang dibawakan oleh Hendrika Bete, S.Pd., M.Pd dan diberikan layanan konsultasi gambaran proposal. Sama seperti materi-materi sebelumnya, pemateri menanyakan pemahaman mereka tentang artikel ilmiah. Rata-rata para peserta kegiatan tidak mengetahui apa itu artikel ilmiah. Yang mereka ketahui adalah jurnal ilmiah. Karena itu, pemateri menggambarkan dengan baik apa itu artikel ilmiah dan apa itu jurnal ilmiah.

Diakhir dari semua kegiatan pada hari ketiga ini diberikan kesempatan untuk mendiskusikan proposal PTK dari masing-masing peserta.

Salah satu konsep rancangan PTK yang mereka ajukan adalah sebagai berikut:

Masalah yangditemukan dari salah seorang peserta adalah siswa belum mampu menentukan ide pokok.

Bab I. Pendahuluan

A. Latar Belakang

Penyebab:

a. siswa belum menggunakan waktu yang tepat dan baik untuk membaca teks dengan baik.

b. Belum terbiasa untuk membaca teks

c. Kurang literasi / sudut buku

Solusi:

a. Penggunaan waktu yang tepat

b. Membiasakan siswa untuk membaca

c. Perbanyak literasi

Berdasarkan masalah di atas maka judul yang dapat digunakan adalah

"Meningkatkan Pemahaman Siswa Kelas VIB SDN Sasi dalam menentukan ide pokok suatu teks dengan pendampingan membaca intensif"

B. Rumusan masalah: Bagaimana meningkatkan pemahaman Siswa dalam menentukan ide pokok suatu teks dengan pendampingan membaca intensif ?

C. Tujuan Penelitian: Untuk meningkatkan pemahaman Siswa dalam menentukan ide pokok suatu teks dengan pendampingan membaca intensif.

D. Manfaat Penelitian: Bagi guru, Bagi siswa dan Bagi Sekolah

E. Batasan Istilah

BAB II LANDASAN TEORI
a. Pemahaman Siswa
b. Ide Pokok Bacaan
c. Membaca Intensif

BAB III Metode Penelitian

A. Jenis Penelitian : Penelitian ini adalah Penelitian Tindakan Kelas (PTK)

B. Waktu dan Tempat Penelitian

Penelitian ini akan dilaksanakan pada semester ganjil 2018/2019, di SDN Sasi

Kefamenanu, Kab TTU

C. Subjek Penelitian

Subjek dalam penelitian ini adalah siswa kelas VI B SDN Sasi

D. Teknik dan Alat (Instrumen) Pengumpulan Data 
1. Alat (Instrumen Penelitian)

* Pedoman Pengamatan untuk siswa dan guru

* Soal Tes Pemahaman

2. Teknik pengumpulan data

* Teknik Pengamatan

* Teknik tes pemahaman

E. Prosedur Penelitian

Gambaran prosedur penelitian sesuai langkah - langkah PTK (Perencanaan, Pelaksanaan, Pengamatan, Refleksi)

Khusus pada langkah Pelaksanaan harus didasarkan pada pendampingan siswa membaca secara intensif.

F. Teknik Analisa Data (tergantung Instrumen)

Pada umumnya, instrumen PTK itu ada pedoman pengamatan dan soal tes. Pada kasus di atas, instrumennya adalah: pedoman pengamatan dan soal tes. Sehingga analisa datanya adalah Data pengamatan dan Data Tes pemahaman siswa (sesuaikan dengan indikator pemahaman siswa)

G. Indikator Keberhasilan

Penelitian dikatakan berhasil jika siswa sudah mencapai pemahaman sesuai dengan standar ketuntasan minimal yang ditentukan oleh sekolah, atau peneliti.

\section{BAB IV: HASIL PENELITIAN DAN PEMBAHASAN}

Disusun sesuai dengan Bab III yakni dengan

* deskripsikan pelaksanaan penelitian dan pengamatan terhadap pelaksaan penelitian

* langkah - langkahnya adalah pelaksanaan, pengamatan, observasi dan refleksi

BAB V: PENUTUP

a. Kesimpulan

b. Saran

Daftar Pustaka.

\section{SIMPULAN}

Berdasarkan hasil kegiatan pengabdian dengan judul "BIMTEK penulisan proposal dan artikel ilmiah penelitian tindakan kelas kepada guru - guru matematika se - Kabupaten TTU" kebanyakan guru - guru sangat antusias dan kegiatan seperti ini harus sering dilaksanakan sehingga antara Dosen, Guru bahkan Kepala Dinas PPO menjadi mitra kerja dalam meningkatkan budaya mutu pendidikan di Kabupaten TTU. Upaya peningkatan mutu tentu haasilnya bukan hanya untuk para siswa tetapi juga untuk meningkatkan kesejahteraan guru guru. Manfaat lainnya yang diperoleh guru - guru adalah mereka lebih memahami bagaimana teknik penulisan yang baik dan benar pada penelitian tindakan kelas dan bagaimana menulis artikel ilmiah yang baik dan benar. Harapannya setelah mengikuti kegiatan ini guru - guru memiliki pengetahuan baru dalam menulis karya ilmiah, konsep-konsep rancangan penelitian yang telah dimiliki dilanjutkan sampai memperoleh suatu artikel ilmiah.

\section{UCAPAN TERIMA KASIH}

Tim Pengabdian mengucapkan limpah terima kasih kepada LPPM yang telah memberikan dana pengabdian demi terlaksananya pengabdian ini, dan semua pihak yang telah bekerjasama.

\section{DAFTAR PUSTAKA}


Arikunto, S. 2006. Penelitian Tindakan Kelas. Jakarta: PT Bumi Aksara

Arikunto,S, Suhardjono \& Supardi. 2008. Penelitian Tindakan Kelas. Jakarta: Bumi Aksara

Dwiloka, B. 2005. Teknik Menulis Karya Ilmiah. Jakarta: Rineka Cipta,

Kementerian Pendidikan Nasional. 2006. Peraturan Menteri Pendidikan Nasional Nomor 22 Tahun 2006 tentang Standar Isi

Mamoh, O. 2018. Meningkatkan Keterampilan Penulisan Proposal Penelitian Tindakan Kelas Bagi Guru Sdn Saenam. UNIMOR, Cendana Bakti Jurnal.

Siswono, T. Y. E. 2010. Penelitian Pendidikan Matematika. Surabaya: Unesa University Press

Sudarsono, FX. 2001. Aplikasi Penelitian Tindakan Kelas. Jakarta: PAU Peningkatan dan Pengembangan Aktivitas Instruksional, Ditjen Dikti Depdiknas

Suwandi, S. 2007. Penelitian Tindakan Kelas. Surakarta: Panitia Sertifikasi Guru 